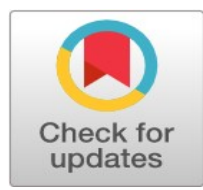

\title{
The effect of investment decision financing decision dividend payment policy and company size
}

\author{
Risal ${ }^{1 *}$, Kristiawati Endang ${ }^{2}$ \\ ${ }^{1,2}$ Economic Faculty, Panca Bhakti University, Pontianak, Indonesia
}

\author{
Index Terms \\ Internal factors \\ Company value \\ Financing decision
}

Received: 18 January 2017

Accepted: 21 March 2017

Published: 21 April 2017

\begin{abstract}
The company value is a picture of the conditions or specific circumstance of the objective of the company through the process of activity over a period that can provide confidence and assurance to the public against the company. This research aims to examine and analyze the effect of the investment decision, financing decision, dividend payment policy and company size on company value. The population of this research is manufacturing companies listed in Indonesian Stock Exchange in the period 2010-2014 with a population of 143 companies. Sampling was done by using purposive sampling method and produced 116 companies as research samples. The method used is quantitative method. Multiple regression model was used to test the relationship between the dependent and independent variables. The results of multiple regression analysis showed that the financing decision variable has a significantly positive effect on the company value with a significance level of 0.000. The dividend payment policy has a significant positive effect on the value of the company with a significance level of 0.007 . The company size variable has a significantly positive effect on the company value with a significance level of 0.000 . While the investment decision variable did not find effect on company value. This research implies that a) the company should consider investment decision making to be made through careful planning for expansion, equipment purchases or investment in any form, b) the company should make financing decision in a planned way, c) the company should be more careful in deciding policy on profit distribution, whether it will be distributed in the form of dividend or capital gain, d) a company that has assets of more than the level of certainty the company will also increase, that affects the high company value in the eyes of investors.
\end{abstract}

(C) 2017 The Author(s). Published by TAF Publishing.

\section{INTRODUCTION}

A company has a goal to increase the company value. With higher company value, the prosperity of shareholders will be increased (Wahyudi \& Pawestri, 2006, Alfian \& Tresna, 2017). The company value can be seen from the price book value (PBV), which is the ratio between the share price and book value per share (Ang, 1997). It shows that almost all of the investment decisions in the stock market are based on the development PBV. High PBV will make investor believe in the prospect of the company to the next Ahmed \& Nanda (as cited in Mulianti, 2010). Based on research that has been done on the value of the company, there are sev- eral factors that affect the value of the company, including the financing decision, dividend policy, investment decision, capital structure, asset growth, company size, profitability, inflation rates and interest rates. Some of these factors have a relationship and influence on the value of companies that are not consistent. Management is required to increase the value of the company through the various means with regard to decision-making.

The decisions in question are investment decision, financing decision and dividend policy. The investment decision is a matter of how the financial manager allocates funds into other forms of investment which is expected to

\footnotetext{
${ }^{*}$ Corresponding author: Risal

†Email: ichal_mks04@yahoo.com
} 
be profitable in the future. According to signaling theory, investment sends a positive signal about the company's growth in the future, so the increasing share price is used as an indicator of the company value (Wahyudi \& Pawestri, 2006). The decision concerning the investment will determine the source of funds for financing. Sources of funds are usually obtained from internal or external funds, both debt and equity capital. On the financing decision, managers are required to consider and analyze the combination of sources of funding that are economical for the company to study investment requirements, so as to optimize the company value that is reflected in its share price. According to Brigham \& Houston (2001) the increase in debt is defined by outsiders as ability of the company to pay its obligation in the future or the low business risk, it will be responded to positively by the market.

Regarding the dividend payment policy, management should consider the interest of investor and the company interests with regard to the management of profit. Investor expects a return in the form of dividend, while the company expects continuous growth in order to survive (Wijaya, Bandi \& Wibawa, 2010; Phyoe, 2015). Manager must decide whether the profit obtained during the period by the company will be shared fully or only partially distributed as dividends and the remainder will be retained by the company often called retained earnings (Noerirawan, 2012). In addition to the above decision, the company size is also a concern of investor. The company size can be seen from the level of sales, amount of equity, or the amount of assets owned by the company and its stock market capitalization. Theoretically, the larger company has certainty that is larger than the small firm that will reduce the level of uncertainty about the company prospect ahead.

It can help investor predict the risk that might occur if he is investing in the company. The research discusses that the company value still has not shown consistent results on the relationship between variables. Research conducted by Wijaya et al. (2010) showed that partial investment decision, financing decision and dividend policy had a positive effect on company value. Similar results were found in studies of Achmad \& Lailatul (2014) which prove that the financing decision and dividend policy have positive and significant impact on the value of the company, but the investment decision does not show any effect on the dependent variable. Another case is the results of research conducted by Suroto (2015), his findings proved that the investment decision has significantly positive effect on the company value, but financing decision has a significant im- pact negatively on the company value and dividend policy has no proven effect. While the research conducted by Sofyaningsih \& Hardiningsih (2011) shows that the dividend policy is shown to affect the company value. In Kristianto's research (2010) on company size variable, he found that the company size has positive effect on company value. The study was conducted on manufacturing companies listed on the Indonesian Stock Exchange. In line with the results of research conducted by Sujoko (2007) and Pratama \& Gusti (2016), which showed the company size has a significantly positive effect on company value. In contrast to the result found by Setiadewi \& Ida (2014) and Hargiansyah (2015) that proves the company size does not have any influence on the company value significantly. Based on the research result, the result has been inconsistent, the researcher conducted this research in order to test the effect of the investment decision, financing decision, dividend payment policy and the company size on the company value in the manufacturing companies listed in Indonesian Stock Exchange.

\section{LITERATURE REVIEW AND HYPOTHESIS DEVELOP- MENT}

\section{Signaling Theory}

According to Brigham \& Houston (2011), cue or signal is an action taken by the company to give guidance to investors on how to look at the management company's prospects. This signal is in the form of information about what has been done by the management to realize the wishes of the owner. Information issued by the company is important, because of its effects on investment decisions parties outside the company. Such information is important for investors and businessmen because the information is essentially presenting information, records or images, both for the state of past, present and future for the survival of the company and its effect on the company. The use of signaling theory in the research related to the capital market was first used by Leland \& Pyle (1977) which states that the company of good quality would deliberately give a signal to the market, so the market can differentiate good and bad quality.

Signaling theory stated investment spending sends a positive signal about the company's growth in the future, thus increasing the share price as an indicator of the value of the company (Hasnawati, 2005; Layyinaturrobaniyah, Masyita \& Sekartadjie, 2016). The increase in debt can also be interpreted outside parties about the company's ability to pay its obligations in the future or low business risk, so the addition of the debt would give a positive signal 
(Brigham \& Houston, 2011). This is because the company increasing the debt can be viewed as a company that is confident in the company's prospects in the future. Dividend policy is often perceived as a signal for investors in assessing the merits of the company, this was because the dividend policy could bring effect on the company's stock price. An increase in the dividend is considered as a signal through which the company's management predicted good earnings in the future (Brigham \& Houston, 2011). The use of dividend as a signal in the form of an announcement which stated that a company has decided to increase the dividend per share may be interpreted by investor as a good signal, because the higher dividend per share indicates that the company is confident that future cash flow will be large enough to bear the level of high dividend (Weston \& Copeland, 1997). Theoretically larger companies have greater certainty than the small company that will reduce the level of uncertainty about the company prospects in the future. It can help investor predict the risk that might occur if he invested in the company. The size of the company can be used as a proxy for the level of uncertainty stock for large-scale companies that tend to be more wellknown in the community, so that information about the prospect of large-scale companies is more easily obtained by investors rather than small-scale companies (Nurhidayati \& Indriantoro, 2002). The level of uncertainty that would be faced by investor about the company's future can be minimized if the issuer gets more information. Information on the company size can assist investor in determining a decision to invest in a company. This is a signal that is responded positively by investor

\section{Company Value}

The company value can show or describe the specific circumstances achieved by a company through the process of activities for several years so as to give confidence to the community against the company. The company value is considered by investors because the higher and increasing value of the company would be an achievement that affects the welfare of the company's shareholders. According to Ohlson (1995), the company value indicates the value of various assets owned by a company, including securities' issuance. The value of the company is reflected in the accounting data contained in the financial statements.

\section{Investment Decision}

According to Martono \& Agus (2005) is an investment fund which is invested by a company in an asset with the hope to earn in the future. Meanwhile, according to Myers (1977), Investment decision is contributed between owned asset and investment options in the future with a positive value, so that investment decision can be interpreted as a decision to allocate fund sourced from outside the company in the form of investment. Variable investment decision has been studied by Wijaya et al. (2010) who found that there were significant positive effects on company value in companies listed on the Indonesian Stock Exchange. Results of research conducted by Wijaya et al. (2010) are not consistent with research conducted by Setiani (2013), which proves that the investment decision has no influence on the company value.

\section{Financing Decisions}

The financing decision by Hasnawati (2005) is defined as decision related to funding composition chosen by the company. Meanwhile, according to Darminto (2010), the financing decision regarding the composition of financing in the form of owner's equity, Long-term liabilities and liabilities are short-term or current liabilities. Sources of capital can come from long-term loans, increase the capital itself derived from retained earnings and the stock issuance. The study conducted by Fama \& French (1998) showed that the return on investment through leverage activity sends a positive signal about the prospects of a company that is a picture or conditions in the future, so it can affect the increased value of the company on the side of investors. The same result is shown in research of Achmad \& Lailatul (2014) who found that financing decisions have significantly positive effect on the company value. However, Suroto (2015) showed different results which found that the funding decisions have a significant negative effect on the company value.

\section{Dividend Payment Policy}

Dividend policy according to Brigham \& Houston (2001) is a decision about how much current profit to be paid as dividends rather than retained to be reinvested in the company. Meanwhile, according to Van Horne \& Wachowicz (1997), dividend policy is closely related to enterprise funding decisions. The amount of dividends distributed to shareholders is very dependent on the amount of income to be detained as a funding source. The smaller the retained earnings, the greater the amount of profit that is distributed in the form of payment dividend. Allocation of retained earnings is a decisive determination in dividend policy. Policies regarding the dividend have been studied by Sujoko \& Ugy (2007) 
which shows that dividend payments have a positive effect on firm's value. However, these studies are not in line with Suroto (2015) which proved dividend policy does not affect the company value.

\section{Company Size}

The company size is described as the size of a company that can be assessed from the total assets, total equity and the level of sales that are owned and displayed at the end of the year in the company's balance sheet. Wahidahwati (2002) showed that the larger the company, the more money that is used to run the operations of the company itself. One source is the debt of the company. Large companies tend to have easier access to capital markets because it has a high degree of certainty in attracting public trust, and thus more able to obtain funds from outside the company. The study conducted by Sujoko (2007) and Sujoko \& Ugy (2007) indicates that company size has significantly positive effect on the firm's value. However, different results are found by Hargiansyah (2015) which proves that company size has no effect on company value.

\section{RESEARCH METHODOLOGY}

In this study, the research object is the company value. The population of this research is manufacturing companies listed on Indonesian Stock Exchange (IDX) in the period 2010-2014 with a population of 143 companies. Sampling was done by using purposive sampling method and produced 116 companies as samples with the selection criteria of a company listed on the Indonesian Stock Exchange (IDX) and the company-published financial statements during the period 2010-2014. The method used is quantitative method. The independent variables in the study is the Investment Decision (X1), Financing Decisions (X2), Dividend Payment Policy (X3), and Company Size (X4). While the dependent variable is the Corporate Value (Y). The models in this research are as follows:

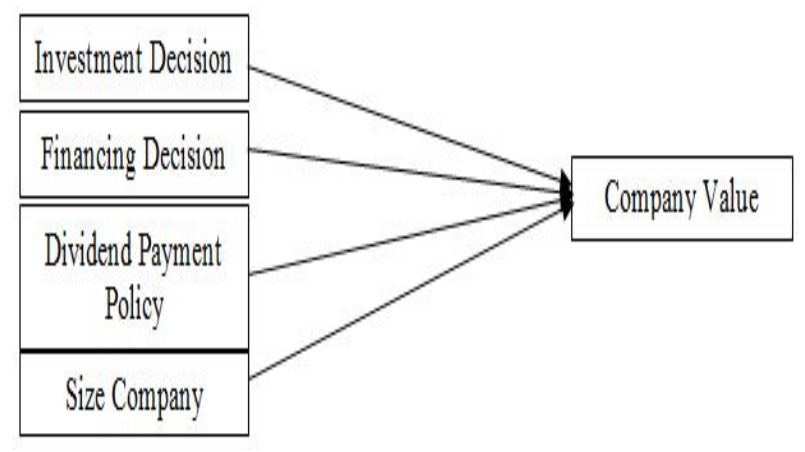

FIGURE 1. Research model
Data analysis techniques used are: 1 . The quantitative descriptive test aims to obtain an overview of the data used. 2. Classic assumption test is done in order to avoid bias or spurious regression on the research results. 3. Statistical tests with three (3) ways: a. Coefficient determination test was conducted in order to gauge how far the ability of the model to explain variations in the dependent variable. $b$. Test the feasibility of the model used to test whether the independent variables simultaneously affect the dependent variable. c. Individual parameter significance test basically shows how far the effect of an independent variable individually / partially explains the variation in the dependent variable. The regression formula is formed as follows:

$\mathrm{Y}=\mathrm{b}_{0}+\mathrm{b}_{1} \mathrm{X}_{1}+\mathrm{b}_{2} \mathrm{X}_{2}+\mathrm{b}_{3} \mathrm{X}_{3}+\mathrm{b}_{4} \mathrm{X}_{4}+\mathrm{e}_{1}$

The following are formulation of a hypothesis at this research:

Ho1: $\mu \leq \mu 1$ There is no positive effect of the investment decision on the company value.

Ha1: $\mu>\mu 1$ There is a positive effect of the investment decision on the company value.

Ho2: $\mu \leq \mu 2$ There is no positive effect of the financing decision on the company value.

Ha2: $\mu>\mu 2$ There is a positive effect of the financing decision on the company value.

Ho3: $\mu \leq \mu 3$ There is no positive effect of the dividend policy on the company value.

Ha3: $\mu>\mu 3$ There is a positive effect of the dividend policy on the company value.

Ho4: $\mu \leq \mu 4$ There is no positive effect of the company size on the company value.

Ha4: $\mu>\mu 4$ There is a positive effect of the company size on the company value.

\section{DATA ANALYSIS}

\section{Descriptive Statistics}

TABLE 1. Descriptive statistics

\begin{tabular}{llllll}
\hline \hline & N & Minimum & Maximum & Mean & Std. Deviation \\
\hline KI & 580 & -239.39 & 119389.00 & 226.8077 & 4957.16819 \\
KP & 580 & -31.78 & 70.83 & 1.4830 & 4.76364 \\
KD & 580 & -418.40 & 24080.78 & 147.9987 & 1502.19462 \\
SIZE & 580 & 9.27 & 19.28 & 14.2417 & 1.60988 \\
NP & 580 & -9.02 & 47.27 & 2.4750 & 5.43296 \\
Valid N (listwise) & 580 & & & & \\
\hline \hline
\end{tabular}

Based on the output of descriptive statistics, known samples used were 116 companies with an average firm value of 2.47, minimum value of -9.02 and maximum value of 47.27. Investment decisions have an average value of 
226.81 with a minimum value of -239.39 and a maximum value of $119,389.00$. The financing decision has an average value of 1.48 with a minimum value of -31.78 , and the maximum value of 70.83. Dividend policy has an average value of 147.99 with a minimum value of -418.4 and a maximum value of 24080.78 . Scale or size of the company has an average value of total assets of 14.24 with a minimum value of 9.27 or in rupiah at Rp. 10.583 billion while the maximum value of 19.28 with the total assets of Rp. 236,029,000,000,000.

\section{Classic Assumption Test Normality test}

TABLE 2 . Results of normality test

Residual Terstandarisasi

Asymp. Sig. (2-tailed) 0.463

This research conducted data normality test using Kolmogorof-Smirnov (Suliyanto, 2011). Standardized normal residual value if the $\mathrm{K}$ count $<\mathrm{K}$ table or the Sig. $>$ Alpha $(\alpha=0.05)$. The test results are known that significant value is greater than the value of alpha $(0.463>0.05)$, so it can be interpreted that research data are normally distributed.

\section{Multicollinearity Test}

TABLE 3 . Results of normality test

\begin{tabular}{lll}
\hline \hline Statistics collinearity & & \\
\hline Variable & Tolerance & VIF \\
\hline \hline $\mathrm{KI}$ & 0.999 & 1.001 \\
$\mathrm{KP}$ & 0.999 & 1.001 \\
$\mathrm{KD}$ & 1.000 & 1.000 \\
$\mathrm{SIZE}$ & 0.998 & 1.002 \\
\hline \hline
\end{tabular}

From the Multicollinearity test results conducted by the researchers, it is known that the tolerance value for all the independent variables is greater than 0.10 , namely investment decision amounted to 0.999 , financing decision amounted to 0.999 , the dividend policy for 1000 , the company size amounted to 0.998 while the value of Variance Inflation Factor (VIF) that was smaller than 10 investment decision amounted to 1.001, financing decision amounted to 1.001 , the dividend policy for 1000 , the size of the company amounted to 1.002 . So we can conclude that the regression model formed no symptoms of Multicollinearity.

\section{Heteroscedasticity Test}

TABLE 4. Results of heteroscedasticity test

\begin{tabular}{lll}
\hline \hline Variable & T & Sig. \\
\hline KI & -0.635 & 0.525 \\
KP & 3.096 & 0.272 \\
KD & 0.546 & 0.585 \\
SIZE & 4.425 & 0.163 \\
\hline \hline
\end{tabular}

From the Heteroscedasticity test results using Glejser methods, it is known that the level of significance of each independent variable is above 0.05 , the investment decision amounted to 0.525 , financing decision amounted to 0.272 , dividend policy amounted to 0.585 and the size of the company amounted to 0.163 . This shows that none of the independent variables significantly affects its absolute value, so it can be inferred that the regression model shows no symptoms of Heteroscedasticity.

\section{Autocorrelation Test}

TABLE 5 . Results of

autocorrelation test

\begin{tabular}{ll}
\hline \hline Variabel & Durbin-Watson \\
\hline & 2.030 \\
\hline
\end{tabular}

Autocorrelation test result using the Durbin Watson in this study of was 2.030 that lies between the values of $\mathrm{dU}$ (1.876) and 4-dU (2.124). These test results indicate that the regression model did not contain the autocorrelation problem.

\section{Multiple Regression Analysis} The coefficient of determination (Adjusted R2)

TABLE 6 . Results of coefficient of determination

\begin{tabular}{lll}
\hline \hline R & R Square & Adjusted R Square \\
\hline $0.273^{\mathrm{a}}$ & 0.074 & 0.068 \\
\hline \hline
\end{tabular}

Table 6 presented the results of the regression test, in which the R2 value amounted to 0.068 , which means that $6.8 \%$ of the variation of the company (NP) can be explained by four independent variables that is investment decision (KI), financing decision (KP), policy payment dividend (KD) and the company size (SIZE) while the remaining 93.2\% 
is explained by other variables that are not tested in this model.

\section{Feasibility Model Test (Test F)}

TABLE 7 . Results of feasibility model

\begin{tabular}{llllll}
\hline \hline Model & Sum of Squares & df & Mean Square & F & Sig. \\
\hline Regression & 1269.424 & 4 & 317.356 & 11.534 & $0.000^{\mathrm{b}}$ \\
1 Residual & 15820.949 & 575 & 27.515 & & \\
Total & 17090.374 & 579 & & & \\
\hline \hline
\end{tabular}

Regression test results performed in table 7 note that the value of $F$ count on ANOVA amounted to 11.534 while the $\mathrm{F}$ table at 2.38. Thus $\mathrm{F}$ count is larger than $\mathrm{F}$ table, as well as the significant value of $F$ count $(0.000)$ is smaller than 0.05 . So it can be concluded that the model used is worthy (fit).

\section{Hypothesis Testing}

TABLE 8 . Hypothesis testing, H8

\begin{tabular}{|c|c|c|c|c|c|}
\hline \multicolumn{6}{|c|}{ Coefficients $^{\mathrm{a}}$} \\
\hline \multirow[t]{2}{*}{ Model } & \multicolumn{2}{|c|}{ Unstandardized Coefficients } & \multirow{2}{*}{$\begin{array}{l}\text { Standardized Coefficients } \\
\text { Beta }\end{array}$} & \multirow[t]{2}{*}{$T$} & \multirow[t]{2}{*}{ Sig. } \\
\hline & $\mathrm{B}$ & Std. Error & & & \\
\hline (Constant) & -6.128 & 1.944 & & -3.152 & 0.002 \\
\hline $\mathrm{KI}$ & $2.396 \mathrm{E}-006$ & 0.000 & 0.002 & 0.054 & 0.957 \\
\hline $1 \mathrm{KP}$ & 0.213 & 0.046 & 0.187 & 4.652 & 0.000 \\
\hline $\mathrm{KD}$ & 0.000 & 0.000 & 0.108 & 2.700 & 0.007 \\
\hline SIZE & 0.578 & 0.136 & 0.171 & 4.264 & 0.000 \\
\hline
\end{tabular}

Based on the results of multiple regression test performed, it is known that from the four variables studied, only one independent variable that does not significantly affect the dependent variable is the variable investment decisions (KI) that amounted to 0.957 greater than the value of 0.05 . While variable funding decisions (KP), the dividend policy (KD) and the company size (SIZE) have a significant influence on the company's value with sequentially significant value of $0.000 ; 0.007 ; 0.000$ less than 0.05 . Testing the first hypothesis in this research was to examine whether investment decision has a positive effect on company value. Based on the statistical t-test, it is indicated that variable investment decision (KI) has no effect on company value. This is evidenced by the significant value of 0.957 which is greater than 0.05 with a beta coefficient of 0.02 and $t$ value of 0.054 so the first hypothesis that stated investment decision positively affects the company value, cannot be accepted. Testing the second hypothesis in this research was to examine whether financing decision has a positive effect on company value. Statistical test results showed that the variable $t$ financing decision (KP) has a positive effect on company value. This is evidenced by the significant value of 0.000 that is less than 0.05 with a beta coefficient of 0.187 and $t$ value of 4.652 so that the second hypothesis which states financing decision has a positive effect on the company value, is accepted.

Testing the third hypothesis in this research was to examine whether the dividend payment policy has positive effect on company value. $\mathrm{T}$ statistical test results indicate that the variable dividend payment policy (KD) has a positive effect on company value. This is evidenced by the significant value of 0.007 which is less than 0.05 with a beta coefficient of 0.108 and $t$ value of 2.700 so the third hypothesis which states dividend payment policy has a positive effect on the company value, is accepted. Testing the fourth hypothesis in this research was to test whether the company size has a positive effect on company value. T statistical test results show that the variable company size (SIZE) has a positive effect on company value. This is evidenced by the significant value of 0.000 which is less than 0.05 with a beta coefficient of 0.171 and $t$ value of 4.264 , so the fourth hypothesis which states the company size has a positive effect on the company value, is accepted.

\section{DISCUSSION}

Results of tests performed partially showed that of the four variables studied, only one independent variable that does not significantly affect the dependent variable is the variable investment decision (KI) which amounted to 0.957 greater than the value of 0.05 . While variable financing decision (KP), the dividend policy (KD) and the company size (SIZE) have a significant influence on the company's value with a sequentially significant value of $0.000 ; 0.007$; 0.000 less than 0.05 . Not influential investment decision on the value of the company may be caused due to incorrect decision-making of managers to invest in a sector or a particular field.

In addition, investors may think that the amount of the investment in the company to invest is in proportion to the inherent risk to be borne in the future, so that investors paid little attention to investment activities undertaken by the company. The results of this research are consistent with research conducted by Achmad \& Laylatul (2014) which proves that the investment decision variables did not significantly affect the value of companies in the manufacturing companies listed on Indonesian Stock Exchange during the period 2010-2012. Similar results were found by Setiani (2013) which proves that the investment decision has no significant and negative effect on firm's value. Fi- 
nancing decision has a significantly positive effect on firm's value. This suggests that if funded through debt financing, the increased value of the company is due to the effect of tax deductible, where the condition of companies that have debt will pay interest on the loan to reduce taxable income. According to Sujoko (2007) the manager will try to increase the level of debt up to a point where the value of the additional interest tax shelter is completely offset by the additional costs of financial problems (Brealey, Stewart, Myers \& Alan, 2008; Dianita, 2015).

From these statements, it can be concluded that the use of debt by the company limits the optimal point in the increased value of the company. The use of debt over the limit will tend to lower the value of the company. The decision in the use of funds through debt sends a positive signal for investors, whether the funds will be used for investment activities, expansion or purchase of equipment, which in turn will give you an advantage in the future so that it can enhance firm's value. Dividend policy has a significant positive effect on firm's value. Dividend is giving some of their profits to shareholders each year. Therefore, investors will receive dividends if the company managed to record a profit.

Of eyewear companies, the dividend distribution is consistent every year that demonstrates the success of management in running the company as well as shows stable cash flow of the company. Eventually it will grow and increase investors' confidence in the company so the company's value will increase. The increase in the dividend is usually a signal to investors that the company's management predicts a good income in the future. Conversely, a decrease in dividends or dividend increases that are below normal are believed by investors as a sign that companies will face difficult times in future. The company size has a significant positive effect on company value. The higher the value of the total assets of the company, then the certainty of company will also increase, which affects the high value of the company for investors.

With total assets of the company being in high value range, it will be easier to obtain funding from outside because the company has a guarantee of assets. This has become a signal for investors to assess that the company is able to manage its assets properly so as to increase the company value.

\section{CONCLUSION}

1) The first hypothesis which states investment decision positively affects the company value, cannot be accepted.
2) The second hypothesis which states financing decision positively affects the company value, is accepted.

3) The third hypothesis which states financing decision positively affects the company value, is accepted.

4) The fourth hypothesis which states the company size positively affects the company value, is accepted.

5) The value of adjusted R2 of 0.68 means that $68 \%$ of the variation of the company (NP) can be explained by four independent variables that is investment decision (KI), financing decision (KP), the dividend policy (KD) and the company size (SIZE) while the remaining $32 \%$ is explained by other variables that are not tested in this model.

\section{RESEARCH IMPLICATIONS}

1) The results provide empirical confirmation that the company should consider the investment decision to be made through careful planning for expansion, equipment purchases or investment in any form.

2) The results provide empirical confirmation that the company should make decisions in a planned funding. Financing decision through the capital of the company will reflect the state of the company, so that this condition is a signal for investors to be able to invest safely with little risk that the company value will be increased.

3) The results provide empirical confirmation that the company should be more careful in deciding policy on profit distribution, whether it will be distributed in the form of dividends or capital gains. If distributed in the form of dividends, of course this will be a signal for investors to invest in the company, but on the other hand, investors will bear the burden of the tax on dividend distributed.

4) The results provide empirical confirmation that if the company has assets of more value, then certainty of the company will also increase, which affects the high value of the company in the eyes of investors. This has become a signal for investors to assess that the company is able to manage its assets properly so as to increase the company value.

\section{RESEARCH LIMITATIONS}

1) Variables used in this research are still limited, since it is estimated there are many other variables that can affect the company value.

2) The research was conducted within the period of observation that is relatively short, the period from 2010 to 2014 so the number of samples used is very limited. 


\section{SUGGESTIONS}

1) Test the return of independent variables in different periods by avoiding conditions which can provide substantial bias in the study as the crisis period.

2) For further research, authors may add other variables such as capital structure, asset growth, profitability, infla- tion rates, interest rates and can use moderating or intervening variables.

3) The observation period should be extended to obtain more samples so as to obtain results showing better data distribution.

\section{REFERENCES}

Achmad, S.L., \& Lailatul, A. 2014. The influence of investment decision financing decision, dividend policy financial perforon the company value. Journal of Science \& Research Accounting, 3(9): 23-28.

Alfian \& Tresna, M.G. 2017. The influence of company's age and owner's/manager's education on the use of accounting in- formation in small and medium enterprises. International Journal of Business \& Administrative Studies, 3(2): 64-71.

Ang, R. 1997. Book smart Indonesian capital market (The intelligent guide to Indonesian capital market). Jakarta, ID: Media Soft Indonesia.

Brealey, R.A., Stewart, C., Myers, J., \& Alan M. 2008. The basics of companies financial management. Jakarta, ID: Erlangga. Brigham, E.F., \& Houston, J.F. 2001. Financial management. Jakarta, ID: Erlangga.

Brigham, E.F., \& Houston, J.F. 2011. Fundamentals of financial management. Jakarta, ID: Salemba Empat.

Dianita, M. 2015. Role of the internal auditor influence and good corporate governance in banking financial performance against state owned corporation. International Journal of Business \& Administrative Studies, 1(4): 176- 179.

Darminto, A. 2010. The influence of external factors and other financial decision on the company value. Journal of ManageApplications 8(1): 138-150.

Fama, E.F., \& French, K.R. 1998. Taxes financing decisions and firm value. The Journal of Finance 53(3): 819-843.

Hargiansyah R.F. 2015. Effect of company size leverage, and profitability on the Corporate Value. Unpublished doc- toral dissertation, Jember University, Jember, ID.

DOI: 10.1108/JBIM-04-2013-0100

Hasnawati, S. 2005. Dampak set peluang investasi terhadap nilai perusahaan publik di Bursa Efek Jakarta. Jurnal Akuntansi dan Auditing Indonesia, 9(2): 33-41.

Kristianto, R. 2010. Effect of ownership structure capital structure profitability and size company to the corporate val- ues. Unpublished doctoral dissertation, Stie Perbanas Surabaya, Surabaya, ID.

Layyinaturrobaniyah., Masyita, D., \& Sekartadjie, G. 2016. Fundamental and technical analyses for stock investment decision making. Journal of Administrative \& Business Studies, 2(1): 1-7.

Leland, H.E., \& Pyle, D.H. 1977. Informational asymmetries, financial structure and financial intermediation. The Journal of Finance, 32(2): 371-387. DOI: 10.1111/0022-1082.00036

Martono, D., \& Agus, H. 2005. Financial management. Yogyakarta, ID: Ekonisia.

Mulianti, F.M. 2010. Analisis faktor faktor yang mempengaruhi kebijakan hutang dan pengaruhnya terhadap nilai pe- $\quad$ rusahaan (Studi pada perusahaan manufaktur yang terdaftar di bursa efek Indonesia (BEI) periode tahun 2004- 2007). Unpublished doctoral dissertation, Diponegoro University, Semarang, ID.

Myers, S.C. 1977. Determinants of corporate borrowing. Journal of Financial Economics, 5(2): 147-175.

DOI: $10.2307 / 2326770$

Noerirawan, M.R. 2012. Effect of internal and external factors on the company value. Unpublished doctoral dissertation, Diponegoro University, Semarang, ID.

Nurhidayati, S., \& Indriantoro, N. 2002. Analysis of factors influencing on the level underpriced in the initial public of- fering at the Jakarta stock exchange. Yogyakarta, ID: BPFE.

Ohlson, J.A. 1995. Earnings book values and dividends in equity valuation. Contemporary Accounting Research, 11(2): 661-687. DOI: 10.1111/j.1911-3846.1995.tb00461.x

Pratama, I., Gusti, B.A., \& I Gusti, B.W. 2016. Effect of company size and leverage on the company value with profitability as mediating variable. E-Journals Unud Management, 5(2): 22-34. 
Phyoe, E.E. 2015. The Relationship between foreign direct investment and economic growth of selected ASEAN Countries. International Journal of Business \& Administrative Studies, 1(4): 132-146.

Setiadewi K.A.Y., \& Ida, B.A. 2014. The influence of company size and leverage to the profitability and company value. Unpublished doctoral dissertation, Udayana University, Denpasar, ID.

Setiani, R. 2013. Pengaruh keputusan investasi, keputusan pendanaan, dan tingkat suku bunga terhadap nilai perusahaan pada perusahaan otomotif yang terdaftar di bursa efek indonesia. Jurnal Manajemen, 2(01): 23-26.

Sjahrial, D. 2006. Introduction to financial management. Jakarta, ID: Mitra Wacana Media.

Sofyaningsih, S., \& Hardiningsih, P. 2011. Struktur kepemilikan, kebijakan dividen, kebijakan utang dan nilai perusahaan.

Dinamika keuangan dan perbankan, 3(1): 45-50.

Suliyanto, A. 2011. Applied econometrics: Theory and applications with SPSS. Yogyakarta, ID: Andi.

Sujoko, A. 2007. The effect of ownership structure, diversification strategy, leverage, internal factor and external fac- tor on the company value. Unpublished doctoral dissertation, Agustus University, Surabaya, ID.

Sujoko, A., \& Ugy, S. 2007. The effect of shareholding structure, leverage, internal and external factor against corporate value. Journal of Management \& Entrepreneurship, 9(1): 34-39.

Suroto, B.J. 2015. The Influence of investment decision, financing decision dividend policy against company value. Scientific Journal Untag, 4(3): 45-57.

Van Horne, J., \& Wachowicz, J.M.J. 1997. Principles of financial management, Nine Edition. Jakarta: ID: Salemba Empat. Wahyudi, U., \& Pawestri, H.P. 2006. Implikasi struktur kepemilikan terhadap nilai perusahaan: dengan keputusan keuan- gan sebagai variabel intervening. Simposium Nasional Akuntansi, 9: 1-25.

Wahidahwati, W. 2002. Pengaruh kepemilikan manajerial dan kepemilikan institusional pada kebijakan hutang perusahaan:

Sebuah perspektif theory agency. The Indonesian Journal of Accounting Research, 5(1): 10-15.

Weston, F.J., \& Copeland, T.E. 1997. Financial management. Jakarta, ID: Binarupa Aksara.

Wijaya, L.R.P. Bandi. A., \& Wibawa, A. 2010. Pengaruh keputusan investasi, keputusan pendanaan, dan kebijakan div- iden terhadap nilai perusahaan. Unpublished doctoral dissertation, Widya Mandala Catholic University, Indonesia, ID. 